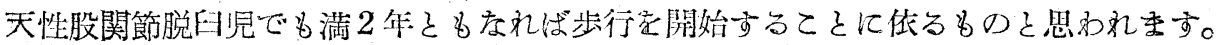
以上先天性股関節脱曰に於ける大腿骨頭核の变化についての第一報として核の未出現及形態に就 て概略報告致しました。

（終りに御指導衔校閲を賜りました島教授に深謝致します）

\title{
( 交献)
}

1) 浜: 先天性股関節脱臼の成因火関する実験的研究, 日本整形外科学会雑誌，5巻，3号 2 ) 神中: 先天性股 関節脱臼，神中整形外科学：㬵関節外科，日本外科学会雑誌，36回，10号 3 ) 本山：人胎児股関節の解剖学的所

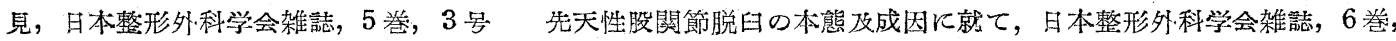
1号 4) 名倉: 先天性股関節脱臼の本態飞就 $て$, 日本整形外科学会雑誌 17 巻, 17号 5 ) 㭅浦: 所謂先天性股 関節脱臼の整復後の股関節の変化に就て，日本整形外科学会雑誌，2巻，1号 6 ) 高木：先天性:股関節脱日，日 本外科学会雑誌, 36 回, 10 号

Department of Orthopedic Surgery, Kurume Medical College (Prof. K. Shima).

Changes of the Femoral Head in the Congenital Dislocation of the Hip.

By

\section{Keishun Nishi,}

Roentgenographic observations about changes of the femoral head in the congenital dislocation of the hip before the reduction are as follows;

1. Delayed appearance of the ossific center of the femoral head seems to be unsignificant for the congenital dislocation of the hip.

2. Dislocated heads of the hip have generally ordinary forms under two years of age, while above two years of age increase remarkably the unordinary.

\section{新鮮開放性骨折の創内骨接合術について}

\author{
三井三池銀業所病院外科塚本俊明
}

（本稿の大要は第一回西日本整形災害外科集談会に於て発表した）

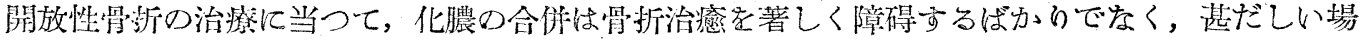

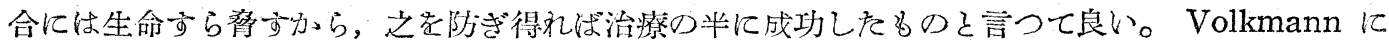
よると，Lister の制管法創始以前に於ける長管骨開放性骨折の死亡率仿 $40 \%$ にる達しているが， Friedrich の第一期創切除法か沁用されるようになつてからは，死亡率も化膿为減少し，Riemann， Böhler, Ehalt 等は夫々優秀な治療成績を報告している。そ祅でも佾，Ehalt は $8.66 \%$ 重篤孛 創障碍に汹まされている。

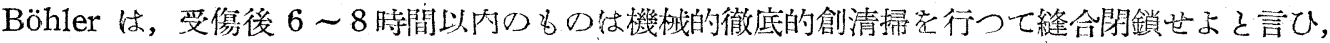

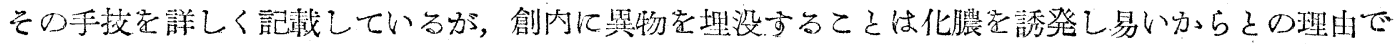


血管結禁や断裂組織の縫合も制限し，ましてや異物を以て骨接合を行うょうなてとは堅く禁じ，創 内に於ては骨折の単なる整復動作も行は度い。神中, 高木, 水町諸教授も同様で, 我国では是が従 来の一般的な治療方針のようである。

然し前田氏は，「著しい化膿の危険の認められないるのには手術的潦法老行つても大考名危険は

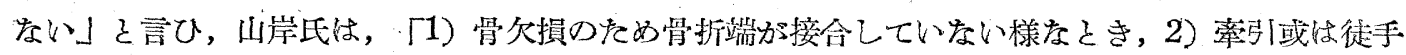
法により適正な整復が得られないとき，3）關節附近の常折で関節成形術が要求される様なとき， には観血的接合術が有利である」と述べている。三未教授が谷大学, 官公立病院气の他の整形外科

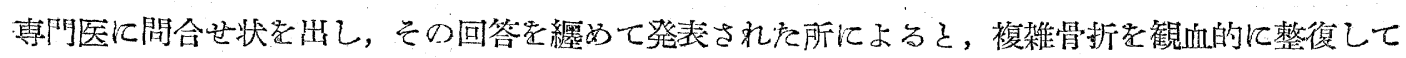
一次縫合孝行う人も少くは孝いが，直に創内で骨接合術索行う人は極く少数のようである。

損㑺重大な新鮮開放性骨折では，創閉鎖後に良好な整復位固定を得ることは決して容易な業では

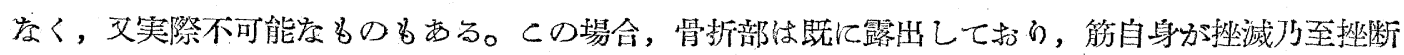

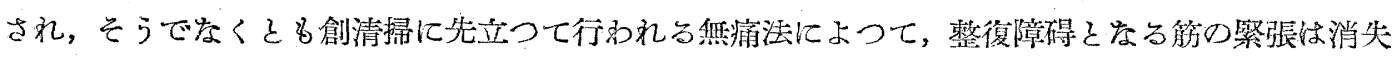
しておるから，直に骨老接合するてとは容易であり，その上で創を一次閉鎖すれば，転位のない固 是性の良い皮下骨䉼として取扱うことが出来る。転位のないものは創処理に止めるこる，転位西る

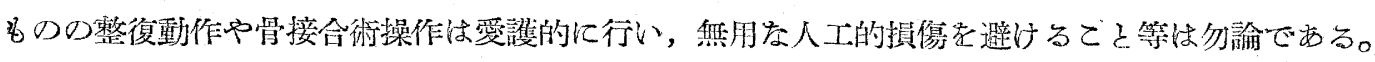

私其の岑坑病院で取扱う外傷は重篤をものが少くないが孝にも新鮮例である。「坑内の創索化膿 させるのは創処理が悪いからだ」とは，経験深い先佂かっら常々教えられておら，堀田氏，当院外科

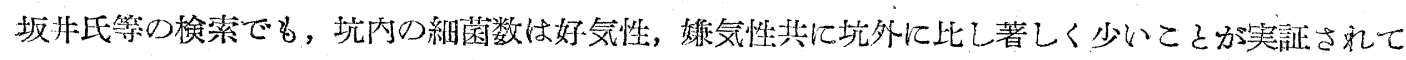
いる。近年抗生物質の研究は急速に進歩し，ペニシリンの偉力怯既に決定的である。挫滅，污染の 猉だしい重症開放性骨捗でも新鮮なるのなら，機㭜的清掃を大念に行いペニシリンを使用すれば， 創内で骨接合術を行つて一次閉鎖しても大なる危険名なからうと考えられる。山岸氏によると, 最

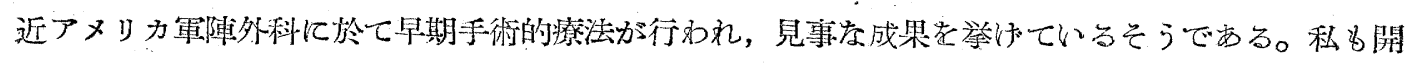

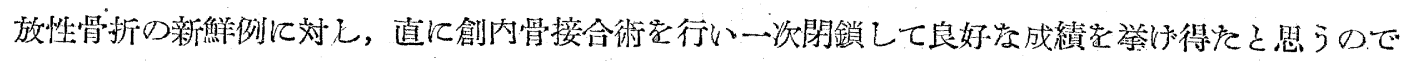
その経験家述べ御批判定公う次第である。

㔊処理：受傷後何時間迄を新鮮とするかは，未だ経 験例が少いので妶に論じないが，私の取报つた例は総 て 6 時間以内である。創清掃こそは化膿防止上の基礎 的要件で西るが，その其体的手技については神中数授 の整形外科手術趋，Böhler 著 Die Technik der Knochenbruchbehandlung “に詳しく記載されて扰り 大体之に做つたのた省略し，私の行つた方法を少し追 加する。

「ショック」状態の者に対し直にリンゲ氏液，荿

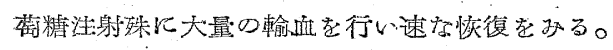

梀裂組織は総て出来るだけ縫合する。縫合不能の腱 久撌部には㨁に自家腱女は筋膜を移植する。筋肉の挫 隇片中活案部を充分飞切除すると大をな久損を生じて
綘合不能をなることは京まするが，機能障碍をずそれ て切除が不充分となり化膿するよりる，必要なたりは 思い切つて切除するが良いと考へる。てのよら年昜合 は腱成形術の考を応用し，筋断端は類似機能を持つ他 の筋に縫合して，幾分でも機能心恢復を是くするよら に心掛汀る。

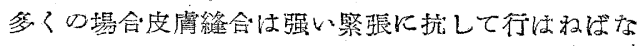

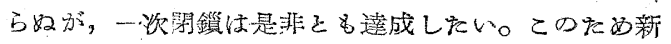
しく切開を加一て皮膚縁をずらし, 又は減張切開を施 す。縫会部の緊張が强過ると末杪が壞死に陷ることが 要る

抜糸の問題は一般に余り注意されないが，挫滅創の

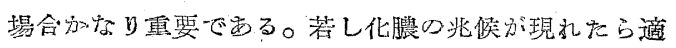


蛋抜糸して充分な排膿を詰り，極力化膿の拡大を防が ねばならぬが，縫合部は或程度湿潤するのが普通です り，文膚縁が一部壊死に陷つたり縫合系のため切れか かつたりすることがあつても，少くをも 2 〜週以上 を経てから抜糸するがよい。さもないと挍糸後，創縁 が哆開し，筋膜や腱が露出して壤死に陷ることさ无 り，治痖に多大の日数を要する汃らである。

骨接合術：創清掃が丁れば直に骨折の整復，接合術

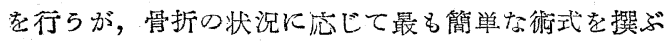
不良な金属は仮骨形成を阻害し化膿誘発の危険が西る し，複雑な操作はそれだけ人工的損甥が㐱くなるから 私は專ら刺戟が少く入手の容易な絹糸で簡単な締結又 は骨縫合を行い，骨移植を併用したこをもある。金属 材料を用いた経験はない。

第 1 表 大院治潦した新僐開放性骨折 患者 (一次切断を除く)

\begin{tabular}{|c|c|c|c|c|}
\hline & 例 数 & 化 膿 & 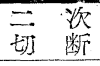 & $\begin{array}{ll}\text { 原 } & \text { 職 } \\
\text { 復 } & \text { 帰 } \\
\end{array}$ \\
\hline 大，腿 霄 & 2 & 0 & 0 & 2 \\
\hline 脛 骨 腓 骨 & 3 & 0 & 0 & 2 \\
\hline 踵骨 & 1 & 0 & 0 & 1 \\
\hline 中足，趾 骨 & 7 & 0 & 1 & 7 \\
\hline 上腕 骨 & 5 & 0 & 2 & 3 \\
\hline 前 腕 骨 & 2 & 0 & 0 & 2 \\
\hline 中手, 指 骨 & 1 & 0 & 0 & 1 \\
\hline 許 & 21 & 0 & 3 & 18 \\
\hline
\end{tabular}

臨牀例：昭租 24 年 11 月以降 26 年 1 月迄の 1 年 2 ケ月 閒に入院せしめて治療した新鮮開放性骨折患者は21名 西り，一見して明瞭な開放性骨折一゙外創もかなり大き く，励染甚だしく，治療の困䨼を思はせるものばかり である(第1表)。その和は末梢部壞死のため二 㳄切断を余儀なくされたが，之を含めて全例に化膿を 防止し得た。代表的な 5 症例を挙け゚ると

症例 1：33歳の採炭工。24年11月22日落磐のため受 傷し約 4 時間後収容。頭蓋底骨折を伴い一般状態不良 左大腿中央に全周の \%を越ゆる挫隇創正り，筋は背側 を除く他の大部分が挫断され眽転し，大腿骨は横骨折

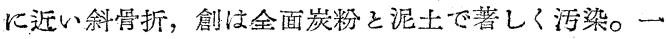
志は切断を考えたが取敢えす翰血 $500 \mathrm{cc}$ の後，機械的 創清掃を入念に行ら。この間，興舊状態を呈し脈摶不 良となつたので輸血を行いつ〉手墭続行。骨に滑止め の目的で鑪きずをつけ絹糸で締結。 P. 20 万年位を創

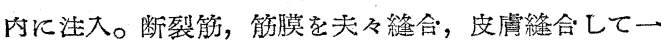

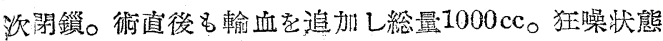

を呈した〉め骨接合部が再り゙軽度転位したので鋼線衰 引。P. 3 万单位宛 3 時間矮皮下泩射総量 233 万单位。 創は第一次治療し骨接合部は約 8 週間後仮骨形成㤐好 で可動性なく，下㬵の短縮 $1 \mathrm{~cm}$ 後潦法を熱心に行 以路行正坐に支障なく筋力も大である。

应例 2：45歳の仕繰工。26年1月 8 日落蒤のため受 側し約 4 時間後収容。在上腕蝧の秒々上方飞長さ 9

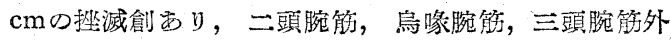
頭, 三角筋附著縁は挫断，中枢骨折片は創外露監，創 は全面多量の炭粉々泥土で污染。主要血管神経の断裂 はない。入念な創清掃。末梢骨折片端が多数の細片に 割れているので，軟部組織との連絡をなるべく損傷し ないよら注意して笴集め絹糸で一括蟐結し，その骨片 中最大のものを内副子として利用し絹糸で両骨折片を 接合。P.10 万单位を注大。各組織を縫合して一次閉 鎻。ギプス繃帯固定。術後前例と同様 $\mathrm{P}$ 泩射総量 234 万単位。創は一期癒合したが仮骨形成遷延したので約 3 ケ月後腸骨櫛より骨片採訤して移植し，約 6 週で仮 骨形成良好。前回埋没した絹糸は著色もせす，炭粉が 少し残つていたが化膿巣中不良肉芽は何処にも見なか 证。

症例 3：5歳の女見，25年 5 月24日りヤカーの車輪 に右腕を插込み，右上腕の肘上方に長さ $5 \mathrm{~cm}$ の挫隇 創あ $\mathrm{n}$, 二頭腕筋，上腕筋は挫断，骨欠損を伴ら顆上 骨折一゙中枢骨折端は創外露出，創は土砂で污染，入念 な凔清掃の後，中枢骨折片端を末梢骨折片の骨髄䐋に 嵌入させ，断裂組織の縫合，P.5 万単位注入して一 次閉鑟。ギプス繃带固定。術後 P. 5 万単位宛 3 時間 每の皮下泩射総量 18 万。一期癒合して退院，家庭の都 合一で 7 週目来院時には癒合强固で，後療法により機能 障碍なく治癒した。

症例 4:29歳の木挽工。24年10月21日製材機で左滕 前面を削取られ，膝蓋骨の未梢 $\%$ ，滕蓋腱の全部を久 損，大腿骨外顆前面にも骨久損，滕関節腔は開放しして いる。創内骨接合例ではないが，㬵蓋腱の代償として 直に大腿広筋膜より筋膜片採取して移植した。 $\mathrm{P}$ 洼入 注 5 万単位。減張切開を加一辛うじて一次開鏆。伸展 位ギプス繃带固定。術後のP 注射総量 216 万単位。繁 張が强かつたので創縁が少し桨開したが化膿すること なく治痖し，滕の伸展力恢復し正坐も可能となつた。

症例 5: 染翻工場の曹達工。25年1月15日ベルトル

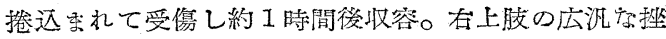

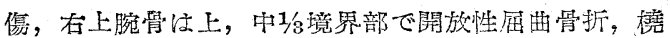
骨動脈々搏は触れ難いが爪床に血行を認める。創処理 
P.10 万单位注入，創内一盛を絹系縫合，一次閉鎻し て外開位ギプス副子固定。辿後のP 泩射総量 210 万单

結
位，末梢部分広沉な壊死に陷り第17日目に二次的に切 断したが化膿をかながた。

\section{語}

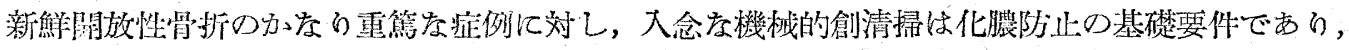
充分な清掃を果し得れば，ペニシリンを使用することにより，創内で通に骨折の整復動作を行い，

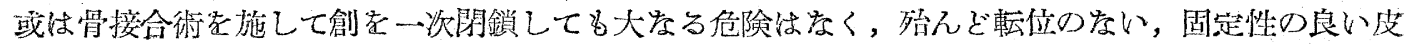
下骨折として取报うことが出来る。このととは期後の治療考容易にし，治療日数の短縮，解剖的 並に機能的治癒にとつて誢だ有利である。

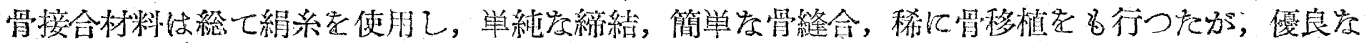

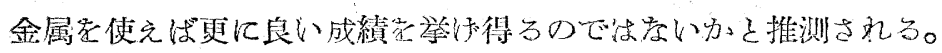

交

1）山岸：複雑骨折と其の後遺症，萌江堂，昭和14年

3) 坂井: 未発表

追加 西日本重工業長崎造船所病院过重行 患者 25 歳 男子 工員

原因改発生状況 25〜9〜16，カバナーの運転試験 中にカプリングボールトイズボンの裾を可办计，モー ターに港をこ采れ右下腿を受傷した。

局所所宽 右下腿下部友側飞長さ 20 糖，巾10糎の創 があり筋腱老筥出挫隇され，両下腿骨の異常可動性著 明で西つて，創腔より脛骨々折端が突出し，足関節む 創底に露われ，サーヂズボンの破片多数が関節腔内に 嵌入散在してぬた。

手術所見 創腔特K足関節腔を清拭し，脛骨に対し 銀線締結をなし，ペニシリン 30 万単位を創府に法入し 一次的に縺合閏鎻し，ギプス副子を装著した。

経，過，翣9〜17ょりペニシリン150万単位 ( 3 万 単位宛每 3 時間) 筋法し, 更飞1日1回1万単位を創 内飞泩入した。何 4 日間はアセトスルフアミン，ロデ フン混合液の動注を併用した処 9 20(術後第4日) K 至り体溫下降し，37度前後となる。其の後はスルフア ダイアデン或はアセトスルフアミンの静泩及でパニー ルチンの皮下泩射により，化膿防止飞妢めた。手術創 は技系後一部多開したが，之は縫合に際し皮䖉を過鹿 飞緊張したための壊死飞因るもので，其の後注良好な 経過を取り，11〜2受傷後 7 週にして，ギプス副子を 除去，11〜18マツ少ーデを開始した処16日後軽度の炎 症を認めたため，1週間中止其の後続行したが 26〜1 〜1 再び静止感染の處があつたので, ペニシリン 120 万单位を注射し, 炎症消退後は直儌運動, 次いで步行 練習をなし，3〜2退院，5〜1より軽作篻に就業してる

\section{嗝}

2) 堀田：第三回日本細菌学丟无州地方会演説，昭和 25 年

る。ツ上，切断を思はしめた高度の挫滅創に於て，ぺ

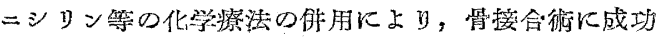
した 1 例を追加報告する。

\section{追加㳩口医大 伊藤鉄 夫}

脛骨中下 3 分の 1 部の新鮮開放性橫骨折の場合には 将来遗延治瘾又,は，仮関節形成をなす場合が少くな い。この場合，腸骨移植を行い，創老閉鎻して良結果 を得を2 症例がある。
追 加
日田市 原文吉

患者注16歳の男児，日田地方で木材運搬に使かれて

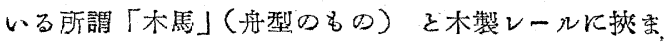
机左下腿は膝閣節下，20粧部一横泚骨折を起し，軟部

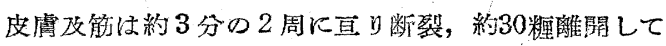
い穼した。機械的に清掃並飞挫隇軟部を切除し，骨折 部は完全に整復した後，軟部の久損に対しては絹糸に よる接近縫合を加え案して。，骨折に剂しては，創们に 固定物質を使用せず，有空ギプス緰鱼を使用するに止

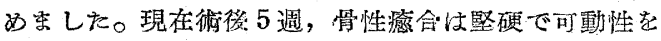
認めず，唯露出した脛骨縁には肉芽の発生痋々として

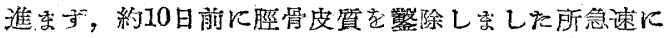
肉芽の発生を見，5 日前飞全創は肉第一゙完全飞被わ斿 るに至り密した。近日中に植皮術施行の予定で画り す。

\section{犋 問 国立久留来病院 岩 崎 高介}

経験浅をため，未执大腿筲折に演者の施された如を

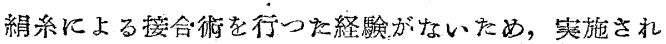

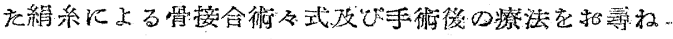
Litur:o 
第

骨接合術式は人工的損傷をなるべく避けるため，簡 単なる方法を採用する。例一ぱ，斜骨折は締結，横骨 折は教科裳記載の如を骨縫命，粉䂗骨折は骨片を出来 るだけ笴せ集めて締結，郝告した第 2 症例では粉确骨
片中の最大のものを内副子として利用，即ち遊離移稙 の形式をとる。

創は極力全閉鑍ず。皮膚欠損のため，縫合因難なる ものは皮薢の成形を行つてでも閉鎻する。後療法は皮 下骨折に準ず。（索引及はギプス繃带）

Department of Surgery, Mitui-Miike Mining Company Hospital.

\section{On the Osteosynthesis of Fresh Compound Fractures in} the Wounds.

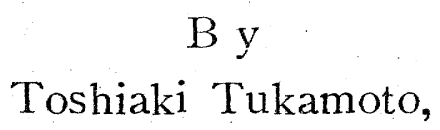

Although only debridgment was used hitherto in fresh compound fractures and the manipulations of fragments in the wounds were prohibited, the great advances of antibiolitics in recent years made it possible to manipulate the fragments in the wounds.

Twenty-one osteosyntheses of fresh fractures in the wounds were performed by author as follows:

After perfect debridgment was done in all cases within six hours after injuries, ruptured soft tissues were sutured as much as possible and the fragments were fixed by single wiring or bone sutures with silks. In some cases complementary sutures for reducing of the tension of skin were necessary, and they were removed at least after 2 or 3 weeks. Penicillin in doses of about 2 million units was used in every case.

Although in all cases the wounds were considerable large and dirty, no suppuration was encountered, after operations.

The author's method is very beneficial for reducing of time of healing and for anatomical and functional healing.

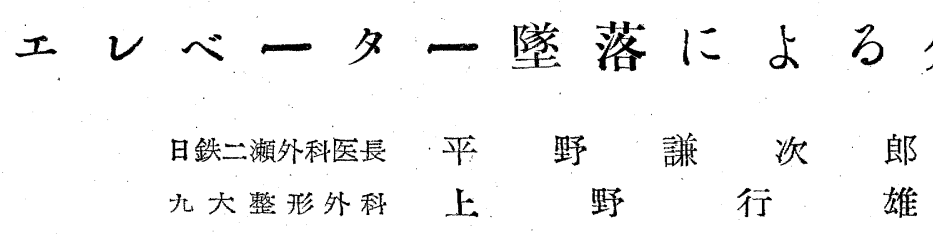

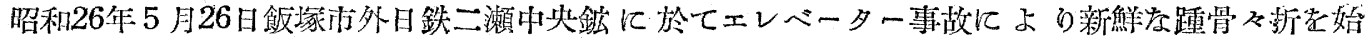

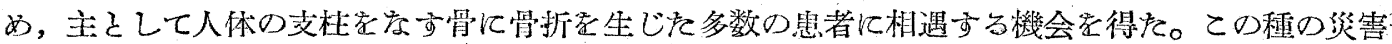

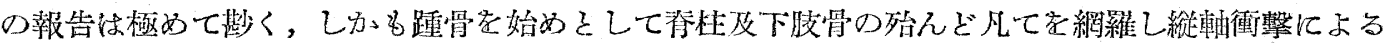
各種骨折を同一事故により多発したるは誠に興味深く，ててに其の大様老報告して御参考に供さん と市。

\section{I 事 故 発生 の 状 況}

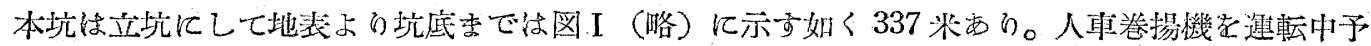

